\title{
Pavoroso espetáculo: o culto ao Vesúvio no Rio de Janeiro oitocentista
}

\author{
Anita Correia Lima de Almeida*
}

Universidade Federal do Estado do Rio de Janeiro, Rio de Janeiro, Rio de Janeiro, Brasil

\section{RESUMO}

Um dos mais célebres vulcóes do planeta, o Vesúvio (Nápoles, Itália), conheceu períodos de intensa atividade no século XIX. Associado ao medo e à desolação, também foi visto, segundo o ideário do romantismo, como uma natureza grandiosa e aterradora, capaz de despertar o prazer do sublime. No Rio de Janeiro, as referências ao vulcão foram numerosas, das notícias na imprensa aos espetáculos do Vesúvio em erupção exibidos nos cosmoramas e em outros entretenimentos ópticos. E finalmente voltaram-se para o imaginário político, com a vinda da imperatriz Teresa Cristina, nascida em Nápoles, e ainda com o fim trágico do líder republicano Silva Jardim, que morreu na cratera do Vesúvio. Entre o desastre, o entretenimento e a política, o objetivo deste artigo é investigar os vários significados que o famoso vulcão assumiu no Rio de Janeiro oitocentista.

Palavras-chave: História dos desastres; História ambiental; Vesúvio; imprensa; Rio de Janeiro.

\section{RESUMEN}

Uno de los más célebres volcanes del planeta, el Vesubio (Nápoles, Italia), experimentó periodos de intensa actividad durante el siglo XIX. Asociado al miedo y a la desolación, también fue visto, de acuerdo con el ideario romanticista, como una naturaleza grandiosa y aterradora, capaz de despertar el placer sublime. En Río de Janeiro, las referencias al volcán han sido numerosas, desde noticias en la prensa hasta los espectáculos del Vesúvio em erupção exhibidos en los cosmoramas y en otros entretenimientos ópticos. Al final, se volcaron hacia el imaginario político, con la llegada de la Emperatriz Teresa Cristina, natural de Nápoles, y con el fin trágico del líder republicano Silva Jardim, quien murió en la cratera del Vesubio. Entre el desastre, el entretenimiento y la política, el objetivo de este artículo es investigar los diversos significados que el famoso volcán asumió en el Río de Janeiro decimonónico.

Palabras clave: Historia de los desastres; Historia ambiental; Vesubio; prensa. Río de Janeiro.

* Professora da Universidade Federal do Estado do Rio de Janeiro. E-mail: anita.correialima@gmail.com. 


\section{ABSTRACT}

One of the most famous volcanoes of the planet, Vesuvius (Naples, Italy), experienced periods of intense activity in the nineteenth-century. Associated with fear and desolation, according to Romanticism it was also viewed as a symbol of nature's grandiose and terrifying features, capable of arousing pleasure and a sense of the sublime. In Rio de Janeiro, references to the volcano were plentiful, from news in the press to spectacles of "erupting Vesuvius" in cosmoramas, and other optical entertainments. Finally, Vesuvius was also used in the political imaginary, with the arrival in the city of Empress Teresa Cristina, who was born in Naples, and with the tragic death of Republican leader Silva Jardim, who perished in the crater of the volcano. Between disaster, entertainment, and politics, this article aims to investigate the various meanings the volcano took in nineteenth-century Rio de Janeiro.

Keywords: History of Disasters; Environmental History; Vesuvius; Press; Rio de Janeiro.

Da atual erupçáo do Vesúvio, o mais importante dos vulcóes existentes na Europa, se ocupa ultimamente toda a imprensa periódica.

Emilio Huelín, Correio do Brazil, 4/7/1872.

O século XIX assistiu a um verdadeiro culto ao Vesúvio e o Rio de Janeiro não ficou de fora. No Rio, o vulcáo frequentou as páginas dos jornais desde os primeiros tempos da imprensa na cidade. A notícia mais antiga que foi possível localizar é de outubro de 1812, ${ }^{1}$ narrava detalhes de uma erupçáo ocorrida em junho do ano anterior e foi publicada no periódico Gazeta do Rio de Janeiro, o primeiro em circulação, criado com a vinda da corte portuguesa poucos anos antes. Ao longo do século, a cada nova erupção as notícias ressurgiam na imprensa fluminense, lembrando a todos a ameaça longínqua, mas permanente, de desastre. Mas o vulcão também esteve presente como deslumbramento, nos cosmoramas e em outros entretenimentos óticos em que o público era convidado a assistir ao espetáculo do "Vesúvio em erupçáo", exibidos na cidade pelo menos desde a década de 1830. E figurou em numerosas referências surgidas a partir da vinda da imperatriz Teresa Cristina (1843), nascida em Nápoles, a região do vulcão e das ruínas de Pompeia e Herculano, as cidades romanas soterradas na erupção de 79 d. C. Finalmente, transformou-se em sinônimo de tra-

\footnotetext{
${ }^{1}$ Gazeta do Rio de Janeiro, 10 de outubro de 1812, p. 3.
} 
gédia, quando Silva Jardim, um dos mais importantes líderes do movimento republicano no Brasil, morreu na cratera do vulcão, pouco antes de completar 31 anos de idade, em $1891 .^{2}$

Foram frequentes, portanto, as mençôes ao monte Vesúvio no Rio de Janeiro do século XIX, capital do império e da república, elas passaram pelas notícias nos jornais e pelos espetáculos óticos, e finalmente alcançaram o mundo da política. Mas o argumento central que se quer desenvolver aqui é o de que há um elemento comum por trás de todos esses papéis que a montanha foi capaz de assumir na cidade. Conhecer a história do famoso vulcão significava adesão ao espírito do cosmopolitismo, por parte das elites, mas também das camadas médias urbanas, na capital do Brasil oitocentista. Significava um gosto pelas viagens e pelas ruínas da antiguidade. Mas significava também, e sobretudo, compartilhar com o público europeu um fascínio pelo desastre, e pelas forças da natureza, com todo o poder de sedução daquilo que podia ser terrível e maravilhoso ao mesmo tempo. Foi daí, segundo o que se pretende sugerir, que a imagem do vulcão tirou a sua maior força. E pôde, afinal, ingressar no imaginário político local.

\section{A fama do vulcão}

O Vesúvio é um dos mais conhecidos e mais estudados vulcôes do planeta, provavelmente porque uniu por milênios uma atividade intensa com a presença de áreas habitadas — e até de cidades inteiras - no seu entorno. ${ }^{3}$ Ao longo do tempo, recebeu uma legião de visitantes e foi representado das mais diversas perspectivas.

O grande marco da história do Vesúvio nos tempos modernos foi a erupção de 1631 . No final daquele ano, depois de cinco séculos de descanso, a montanha sofreu uma violenta erupção, que deixou, segundo algumas estimativas, mais de 4 mil vítimas. ${ }^{4}$ Depois da tragédia, o vice-rei de Nápoles, Emanuel Fonseca, mandou afixar numa parede uma placa de mármore, com um alerta: "Se a história diz a verdade, o Vesúvio, desde que o sol brilha sobre

\footnotetext{
${ }^{2}$ Ver HARDMAN, Francisco Foot. Silva Jardim: a República e o vulcão. Estudos Avançados, São Paulo, v. 12, n. 34, set./dez. 1998. Para outro estudo que aponta para as conexóes entre o interesse pelos vulcóes e o pensamento político, ver DUARTE, Regina Horta. Natureza e sociedade, evolução e revolução: a geografia libertária de Elisée Reclus. Rev. Bras. Hist., São Paulo, v. 26, n. 51, p. 11-24, jun. 2006. Ver também, sobre a erupção vulcânica como alegoria política, do poder dos reis, do fogo revolucionário ou das mudanças forjadas pela industrialização, entre outras acepçóes, referências em DALY, Nicholas. The volcanic disaster narrative: from pleasure garden to canvas, page, and stage. Victorian Studies, v. 53, n. 2, p. 255-285, 2011.

${ }^{3}$ Para uma breve história do Vesúvio, ver DARLEY, Gillian. Vesuvius: the most famous volcano in the world. Cambridge: Harvard University Press, 2012. A última erupção do Vesúvio ocorreu em março de 1944. Desde então, o vulcão entrou em uma nova fase de descanso. Ocorrida durante a Segunda Guerra, com a Itália ocupada pelas forças aliadas, a erupção de 1944 foi muito documentada, por fotógrafos e cinegrafistas, inclusive com imagens aéreas captadas por aeronaves de guerra.

${ }^{4}$ CIVETTA, Lucia et al. (Org.). Il Vesuvio negli occhi: storie di osservatori. Nápoles: Osservatorio Vesuviano/ Istituto Nazionale di Geofisica e Vulcanologia, 2004, p. 11.
} 
a terra, por vinte vezes se inflamou e devorou todos que tardaram a fugir. Previno-vos, para não serdes apanhados de improviso." E a placa segue: "Um dia, cedo ou tarde, o Vesúvio se inflama; lança fogo, fumaça e relâmpagos (...). Fugi antes que seja tarde demais! Logo a montanha se abre e liberta uma torrente de fogo que corre ao longo das encostas e isola os fugitivos atrasados." E conclui: “Tu, que és sensato, escuta estes conselhos. Não te preocupes com tua casa e foge sem hesitar." 5

O retorno do Vesúvio à condição de vulcão ativo trouxe o medo do desastre e da morte. Como alertava a placa do vice-rei, o perigo de ser devorado por uma de suas erupçóes era real. Ao longo dos séculos seguintes, no entanto, o vulcão também foi celebrado. A montanha chamou a atenção de estudiosos do fenômeno vulcânico e a luta moderna para desvendar os seus mistérios começou. ${ }^{6}$ Ao contrário de muitos outros vulcóes, o Vesúvio podia ser observado com relativa facilidade e oferecia uma possibilidade de contato com os sentimentos estéticos do sublime - surgido da observação de uma natureza grandiosa e terrível — e mesmo do pitoresco.?

Nápoles foi um destino quase obrigatório para viajantes no Grand Tour, o costume de fazer um itinerário continental pela Europa, que incluía uma visita a Paris, mas também às principais cidades italianas, uma etapa considerada fundamental na formação dos jovens da aristocracia inglesa e de outros países europeus. E Nápoles seguiu como destino importante ao longo de todo o século XIX, quando o Grand Tour já havia se transformado na ideia romântica de "viagem à Itália" e mesmo esta já começava a ser substituída pelo turismo de massa. ${ }^{8}$

A descoberta das cidades soterradas pelo Vesúvio na erupção de 79 d. C., Pompeia e Herculano (e ainda Stabia ${ }^{9}$ ), na primeira metade do século XVIII, mudou para sempre a história da região. As revelaçóes fizeram o culto ao mundo antigo crescer vertiginosamente e o prazer proporcionado por ruínas romanas alcançou o que já foi chamado de "ponto de embriaguez". ${ }^{10}$ Mas, enquanto crescia a admiração do mundo por Pompeia e Herculano,

\footnotetext{
${ }^{5}$ CORTI, Egon C. C. Vida, morte e ressurreição de Herculano e Pompéia. Belo Horizonte: Itatiaia, 1958, p. 135-6.

${ }^{6}$ Ver COCCO, Sean. Watching Vesuvius: a History of Science and Culture in Early Modern Italy. Chicago: The University of Chicago Press, 2013.

${ }^{7}$ Ver DUFFY, Cian. "This astonishing convulsion of nature": Vesuvius and the spectacle of eruption. In: The Landscapes of the Sublime 1700-1830: Classic Ground. Londres: Macmillan, 2013 e MADERUELO, Javier. La mirada pintoresca. Quintana, Santiago de Compostela, n. 11, p. 79-90, 2012.

${ }^{8}$ Ver BENOIT, Raffaella et al. Turismo e archeologia nel XIX secolo: il ruolo dell'anticonella promozione delle città campane. In: VI CONVEGNO INTERNAZIONALE DI STUDI CITTÀ MEDITERRANEE IN TRASFORMAZIONE. IDENTITÀ E IMMAGINE DEL PAESAGGIO URBANO TRA SETTE E NOVECENTO. Università degli Studi di Napoli Federico II. Nápoles: Edizioni Scientifiche, 2014. Ver também PATIERNO, Alvio. Vesuvius for Everyone in 19th Century France. In: ASCARI, Maurizio; CORRADO, Adriana (Org.). Sites of Exchange: European Crossroads and Faultlines. Amsterdã: Rodopi, 2006, p. 87-95.

${ }^{9}$ As escavaçôes em Stabia começaram em 1749 e seguiram, com intervalos, até a década de 1780, mas daí em diante foram interrompidas e as ruínas novamente enterradas.

${ }^{10}$ Rose Macaulay, em Pleasure of Ruins (1953), citado em SALGUEIRO, Valéria. Grand Tour: uma contribuição à história do viajar por prazer e por amor à cultura. Rev. Bras. Hist., v. 22, n. 44, p. 289-310, 2002.
} 
também aumentava a noçáo do poder da montanha, cuja força eruptiva tinha sido capaz de soterrar as duas cidades por dezesseis séculos. $\mathrm{Na}$ mesma viagem, os visitantes podiam se maravilhar com os segredos revelados das cidades antigas — e Goethe escreveu: "Muita desgraça já aconteceu no mundo, mas poucas capazes de causar tanta alegria à posteridade"11 - e ao mesmo tempo admirar o poderoso vulcáo que as tinha destruído.

Mas o Vesúvio não era apenas um testemunho da História ou uma paisagem a ser captada pelo olhar do artista, era uma força viva. O século XVIII assistiu a mais de uma dezena de suas erupçôes, e elas não foram menos frequentes no século seguinte. No dia 15 de agosto de 1804, por exemplo, o vulcão entrou em atividade e fluxos de lava atingiram dois povoamentos próximos, Torre del Greco e Torre Annunziata. Dois meses mais tarde, a erupção estava encerrada. Em fevereiro de 1805, no entanto, os fluxos de lava estavam de volta. As atividades vulcânicas das décadas de 1820, 1830, 1850, 1860 e 1870 foram particularmente violentas. Em 1841 foi criado o Observatório Vesuviano para monitorar as atividades do vulcão, a primeira instituição do gênero no mundo. Na década de 1870 foi construído um plano inclinado para o transporte de passageiros até o topo da montanha. Pouco a pouco, o interesse pelo vulcáo se popularizava e o acesso à montanha ia se tornando cada vez mais fácil.

\section{A imprensa e as catástrofes}

Ao longo do século XIX, a imprensa foi fundamental para dar visibilidade a terremotos, vulcôes e eventos climáticos extremos. E para tratá-los como modalidades diversas de um mesmo fenômeno, a catástrofe. Mas estudiosos têm alertado para a importância de entender a própria criação da noção de catástrofe, cujo surgimento, que não teria ocorrido antes do século XVIII, estaria ligado a diversos fatores e, entre eles, justamente à importância que a imprensa concederá ao tema.

Ao publicarem a coletânea L'invention de la catastrophe au XVIIIe siècle: du châtiment divin au désastre naturel (2008), ${ }^{12}$ reunindo os textos de um seminário organizado na universidade de Lyon, as pesquisadoras Anne-Marie Mercier-Faivre e Chantal Thomas observaram que, tal como Jean Starobinski mostrou que o século XVIII "inventou” a liberdade, a ideia moderna de catástrofe também surgiu no mesmo século, e por um processo que se deu em vários níveis, na linguagem, quando a palavra, vinda do teatro, ganhou outro significado; na ciência e na filosofia, quando a reflexáo de philosophes e homens de letras libertou a noçáo do campo religioso; e, finalmente, mas não menos importante, no campo político e midiático, a partir do momento em que nasceram as ideias de socorro organizado e de prevenção de

\footnotetext{
${ }^{11}$ GOETHE, Johanes Wolfgang. Viagem à Itália, 1786-1788. São Paulo: Companhia das Letras, 1999, p. 243. ${ }^{12}$ MERCIER-FAIVRE, Anne-Marie; THOMAS, Chantal (Org.). L'invention de la catastrophe au XVIIIe siècle: du châtiment divin au désastre naturel. Genebra: Droz, 2008.
} 
acidentes, fazendo surgir uma nova sensibilidade na opinião pública. Nesse processo, tanto a emoçáo como a curiosidade em relação aos desastres passaram a ocupar um lugar central na imprensa.

A presença da catástrofe nas páginas dos jornais acompanhou o crescimento e as transformaçôes, inclusive dos meios técnicos de difusão da notícia, que marcaram a própria história da imprensa. Para o século XIX, pode servir de exemplo a diferença na repercussão de duas erupçóes vulcânicas, uma ocorrida no princípio do século e outra no final. Na noite de 5 de abril de 1815, o monte Tambora, na ilha de Sumbawa (Indonésia), no que entáo eram as Índias Orientais Holandesas, começou aquela que é considerada a mais poderosa erupção vulcânica registrada na História. Cinco dias mais tarde, o topo do vulcáo explodiu e em seguida a borda da cratera desabou. Difícil de mensurar, o número de mortos já foi calculado em 100 mil pessoas.

Segundo o professor Gillen D’Arcy Wood, da Universidade de Illinois, que publicou recentemente os resultados de uma longa investigação sobre o Tambora, a explosão lançou para o alto uma quantidade prodigiosa de material eruptivo. As partículas mais finas formaram uma nuvem que se espalhou com o vento e bloqueou os raios solares, provocando o resfriamento do planeta nos três anos seguintes. As colheitas foram duramente atingidas em várias regiōes e ocorreram pandemias. Mas esses fenômenos não foram então percebidos como uma consequência da explosão do vulcão. Naquele início do ano de 1815, os olhares estavam voltados para Napoleão Bonaparte. E a notícia da erupção do Tambora levou meses para chegar ao ocidente. ${ }^{13}$

Se alguma outra erupção vulcânica merecesse ser comparada a do Tambora seria a do Krakatoa, ocorrida em 1883, na mesma área de tensão tectônica do Sudeste Asiático. Do ponto de vista de difusão da notícia, no entanto, esses dois eventos igualmente letais, mas afastados no tempo por mais de sessenta anos, sofreram tratamento bastante diverso. O geólogo e jornalista Simon Winchester escreveu a respeito da erupção do Krakatoa:

Pessoas nervosas e fascinadas ao redor do mundo, em cidades táo distantes de Java e uma da outra como Boston de Bombaim (...), todas elas tomaram conhecimento imediato do fato, e assim ocorreu simplesmente por essa ter sido a primeira grande catástrofe do mundo a acontecer em seguida à invenção do telégrafo submarino. Os jornais estavam cheios de notícias a respeito, as descriçôes tornavam os acontecimentos ainda mais fascinantes à medida que eram tâo perfeitamente atuais. Palavras e frases até entáo praticamente desconhecidas — Java, Sumatra, estreito de Sunda, Batávia - passaram, num potente flash de luz eruptiva, a ser de uso corrente de todos. ${ }^{14}$

\footnotetext{
${ }^{13}$ WOOD, Gillen D’Arcy. Tambora: the eruption that changed the World. Princeton, NJ: Princeton University Press, 2014.

${ }^{14}$ WINCHESTER, Simon. Krakatoa: o dia em que o mundo explodiu. Rio de Janeiro: Objetiva, 2004, p. 22.
} 
Entre o silêncio dispensado ao Tambora, em 1815, e o frisson causado pela erupçáo do Krakatoa em 1883, houve a consolidação de um gênero específico, a notícia de desastre, que ao longo do século XIX esteve cada vez mais presente nas páginas da imprensa mundo afora.

\section{O Vesúvio na imprensa fluminense}

O leitor que abriu a edição de 23 de maio de 1872 do Diário do Rio de Janeiro pôde acompanhar as notícias sobre a erupção do Vesúvio ocorrida no mês anterior. O Diário reproduziu matérias de vários jornais estrangeiros sobre a erupção. Um jornal de Nápoles do dia 25 de abril dizia: "A lava (...) começou a correr às 3 horas da tarde, de uma pequena fenda que de manhã se tinha aberto próximo da cratera principal, depois de fortes detonaçóes que durante 48 horas se produziam nas entranhas da terra." Outro jornal de Nápoles, também reproduzido, dizia: "Os feridos, a maior parte deles queimados, por causa da erupção do Vesúvio, e que foram levados para os hospitais, apresentam um aspecto medonho." O jornal informava que essas vítimas eram curiosos que estavam vendo a erupção e que acabaram envolvidos pelas chamas quando subitamente o solo abriu-se em duas partes: "Os seus corpos são uma completa chaga. Estáo envolvidos em panos, náo se podem mover, e o menor balanço fá-los exalar gritos de dor." ${ }^{15}$

O Diário do Rio de Janeiro também reproduziu matéria publicada no dia 27 de abril pelo jornal britânico The Daily Telegraph, em que o correspondente em Nápoles informava: "Fui visitar hoje o Vesúvio e pude ver os terríveis fenômenos desta horrorosa convulsão. Da cratera elevam-se nuvens de fumo, formadas de uma espécie de vapor inflamado." ${ }^{16}$ Segundo a narrativa do correspondente, as detonaçóes se sucediam, com um ruído assustador, assemelhando-se a grandes descargas elétricas, e a cada novo estrondo os caixilhos das janelas voavam em pedaços "como se estivessem na proximidade de uma fábrica de pólvora em explosão". E mesmo os edifícios mais sólidos abalavam-se até às fundaçôes. ${ }^{17} \mathrm{O}$ leitor do Rio de Janeiro também pôde acompanhar a erupção através do Jornal do Comércio, que falou em duzentos mortos sepultados pela lava. ${ }^{18}$ Segundo os vulcanologitas, durante a erupção de 1872, o que houve na madrugada de 26 de abril foi o colapso de uma parte da cratera do vulcáo, acompanhado de abalos sísmicos e de violento derramamento de lava. No dia seguinte, uma alta coluna de material eruptivo lançado na atmosfera podia ser observada de longe.

Catástrofes ocorridas mundo afora ocupavam um lugar importante na pauta dos periódicos do Rio de Janeiro oitocentista. Enquanto terremotos, furacôes, inundaçóes e outros desastres eram cada vez mais incorporados ao noticiário, o Vesúvio, com suas numerosas

\footnotetext{
${ }^{15}$ Diário do Rio de Janeiro, 23 maio 1872, p. 1.

${ }^{16}$ Idem.

${ }^{17}$ Idem.

${ }^{18}$ Jornal do Comércio, 21 maio 1872, p. 8.
} 
erupçóes, ajudava a garantir e renovar esse fluxo de notícias. O mesmo Diário do Rio de Janeiro escreveu, por exemplo, em sua edição de 22 de abril de 1850: "E não escapou este ano sem uma erupção do Vesúvio! E grande e medonha! 54 casas arrastou consigo a lava, e uma igreja (...)." ${ }^{19}$ Já na edição de 31 de março de 1871, o jornal dizia: "À guerra, aos bombardeamentos, aos plebiscitos, aos tremores de terra e às inundaçóes necessário juntar mais uma erupção do Vesúvio.”20

Seria possível multiplicar os exemplos, mas o que interessa ressaltar é que os leitores do Rio de Janeiro oitocentista tinham um acesso fácil e regular às notícias sobre as sucessivas erupçôes do Vesúvio, colhidas nos jornais estrangeiros e reproduzidas na imprensa fluminense desde o seu surgimento. Ao longo do século, a quantidade de periódicos em circulação cresceu vertiginosamente e o número de notícias se multiplicou, mas a mudança mais significativa no noticiário local sobre as erupções do vulcão (e que parece ter acompanhado um processo mais largo de transformação da imprensa periódica como um todo) foi a diminuição progressiva do tempo decorrido entre o evento e a notícia; as erupções chegavam às páginas dos jornais cada vez mais rapidamente. ${ }^{21}$

Outro aspecto a ser observado é que embora as referências ao Vesúvio surgissem a cada nova erupção, elas não estiveram restritas a esses momentos. Em alguns casos, por exemplo, a citação ao Vesúvio serviu como medida para outros desastres. Em dezembro de 1876, um ciclone foi noticiado pelo Diário do Rio de Janeiro: "Chegou-nos da Índia a notícia de um dos maiores desastres da história universal, o ciclone de 31 de outubro de 1876 na costa de Bengala." Procurando chamar a atenção dos leitores para a dimensão do ocorrido, o texto dizia: "Depois do cataclismo que submergiu três cidades, Herculanum, Pompeia e Stabie debaixo das lavas do Vesúvio, não conheço outro desastre que no espaço de poucos minutos fizesse tantas vítimas.". 22

Algumas referências ao vulcão estavam voltadas para a divulgação de teorias sobre as origens do fenômeno vulcânico ou de métodos para prever as erupções. Notícias específicas, como a do uso do sismógrafo introduzido no Observatório Vesuviano por seu diretor, o professor Luigi Palmieri, na década de 1870, também surgiam, como num suplemento do Jornal do Comércio publicado durante a erupção de $1872 .{ }^{23}$ Além de mencionar a introdução do sismógrafo, a matéria também fazia consideraçóes que podem ser lidas como parte do

\footnotetext{
${ }^{19}$ Diário do Rio de Janeiro, 22 abr. 1850, p. 1.

${ }^{20}$ Diário do Rio de Janeiro, 31 mar. 1871, p. 1.

${ }^{21}$ Sobre os desastres e a imprensa, ver BELO, André. A gazeta de Lisboa e o terramoto de 1755; a margem do não escrito. Análise Social, Lisboa, v. 34, n. 151-152, p. 619-636, 2000. Para uma visão mais geral sobre o tema, ver ARQUEMBOURG, Jocelyne. L'événement et les médias: les récits médiatiques des tsunamis et les débats publics (1755-2004). Paris: Éditions des Archives Contemporaines, 2011.

${ }^{22}$ Diário do Rio de Janeiro, 26 e 27 dez. 1876, p. 2.

${ }^{23}$ Jornal do Comércio, Suplemento, 2 jun. 1872, p. 8-9. Sobre a introdução do sismógrafo por Palmieri, ver BORGSTROM, Sven; DE LUCIA, Maddalena; NAVE, Rosa. Luigi Palmieri: first scientific bases for geophysical surveillance in Mt. Vesuvius area. Annali di Geofisica, Roma, v. 42, n. 3, jun. 1999.
} 
processo mais geral de laicização do tema do desastre. O jornal comentava que "no tempo do absolutismo" uma procissão religiosa depois de uma erupção do Vesúvio podia gerar atos de fanatismo, mas no presente a tranquilidade tinha sido mantida e enquanto o professor Palmieri era alvo da admiração da juventude ilustrada, a procissão seguia sem que a "populaça" se lembrasse de pedir contas ao professor, "que pretendia explicar pelas leis da física o recente fenômeno". ${ }^{24}$

Várias inserçóes eram dedicadas à história da erupçáo de 79 d. C. Na ediçáo de 19 de janeiro de 1868, o Diário trouxe a matéria intitulada "A destruiçáo de Pompeia", extraída do London Magazine, que continha uma descrição dramatizada do esplendor da cidade e do desastre que se abateu sobre seus moradores: "Os habitantes morreram nas mesmas posturas em que a catástrofe os achou; os convidados na sala do banquete, os noivos em seus quartos, os soldados nos seus postos, os presos nas masmorras, ladróes no ato do roubo, donzelas defronte do espelho (...)." ${ }^{25}$ A matéria, reproduzida em duas colunas, dava notícia das escavaçôes ainda em andamento: "Novas maravilhas todos os dias saem à luz, e breve teremos uma ideia quase exata d'uma cidade romana no primeiro século da era Cristá", para finalmente concluir: "Pompeia é o fantasma d'uma civilização extinta, erguendo-se ante a nossa vista maravilhada." 26

Algumas notícias supunham leitores familiarizados com a história de 79 d. C. Uma matéria sobre a erupção de 1855, publicada no Diário do Rio de Janeiro, dizia: "Um oficial da marinha dos Estados Unidos, e um jovem alemão, foram vítimas da sua curiosidade como o antigo Plínio!" ${ }^{27} \mathrm{O}$ jornal se dirigia, assim, a leitores que tinham conhecimento das cartas de Plínio o Jovem sobre a morte de seu tio, Plínio o Velho, que tendo assistido ao início da erupção, e sem se deixar tomar pelo desespero geral, viajou perigosamente na direção do vulcão e terminou por morrer vítima de gases tóxicos. ${ }^{28}$

Quando um novo jornal diário foi criado no Rio de Janeiro, com a pretensão, que não se realizou, de que suplantasse os grandes jornais da cidade, ${ }^{29} \mathrm{o}$ Vesúvio não ficou de fora. No ano de criação de $O$ Cruzeiro (1878), foram publicadas seis notas sobre o aumento da atividade vulcânica que vinha ocorrendo em Nápoles. Além disso, o periódico recém-criado também deu notícia do vulcão Cotopaxi (Equador),$^{30}$ que no ano anterior tinha entrado em

\footnotetext{
${ }^{24}$ Jornal do Commercio, Suplemento, 2 jun. 1872, p. 8-9.

${ }^{25}$ Diário do Rio de Janeiro, 19 fev. 1868, p. 2.

${ }^{26}$ Idem. Para outro exemplo, ver a matéria intitulada "Um dia em Pompeia", Jornal do Comércio, 16 abr. 1850, p. 1.

${ }^{27}$ Diário do Rio de Janeiro, 22 abr. 1850, p. 1.

${ }^{28}$ Extratos das cartas de Plínio podiam ser encontrados traduzidos para o português, como, por exemplo, em GUIMARÃES, António J. Memoria sobre as ruínas e as antiguidades de Pompeia. Annaes da Sociedade Literaria Portuense. Porto: Imprensa de Alvares Ribeiro, 1837, p. 31-6.

${ }^{29}$ Ver CRESTANI, Jaison Luís. Sob o signo da rivalidade: o perfil editorial do jornal O Cruzeiro. Miscelânea, Assis, v. 14, p. 141-162, jul./dez. 2013.

${ }^{30} \mathrm{O}$ Cruzeiro, 14 nov. 1878, p. 2.
} 
erupção, quando então terríveis avalanches de lama formadas pelo derretimento da neve na cratera do vulcão, os chamados lahars, devastaram a regiáo.

E há ainda uma última menção ao Vesúvio no jornal O Cruzeiro. Na edição de 21 de maio de 1878, no espaço reservado ao folhetim, Machado de Assis publicou, sob pseudônimo, um texto de crítica satírica chamado "O caso Ferrari", ${ }^{31}$ em que mencionou o vulcão. No texto, um empresário do ramo do teatro peca, se arrepende e diz: "Três vezes tentei matar-me, atirando-me à cratera do Vesúvio."32

\section{Figura 1. Ilustraçâo Brasileira, n. 2, 15 de julho de 1876, p. 15.33}

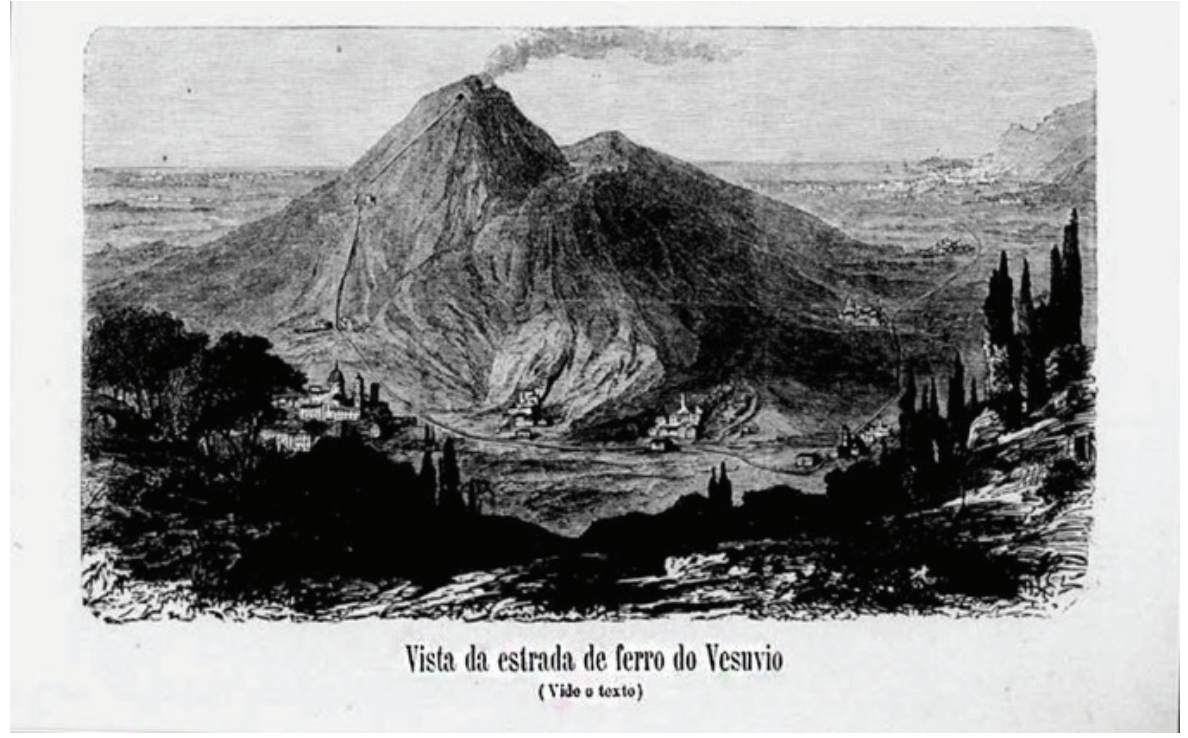

E, finalmente, com o surgimento dos periódicos ilustrados, na segunda metade do século XIX, o vulcáo continuou a manter-se presente nas páginas da imprensa fluminense, agora ocupando espaço também entre as gravuras (Figura 1).

Como se percebe do inventário das referências ao Vesúvio, a imprensa fazia mais do que manter o leitor informado sobre a ocorrência de novas erupçôes ou sobre os avanços da vulcanologia. Ela apelava para o passado do vulcão. Embora inserido no conjunto dos desastres que ocupavam as páginas dos jornais, o Vesúvio não era um vulcáo como os outros. Ele tinha uma história conhecida e palpável para provar o seu poder de destruição. Narrando a morte instantânea "dos convidados nas salas dos banquetes" ou "dos noivos em seus quartos", as matérias sobre as cidades soterradas não deixavam dúvidas quanto à extensão deste poder.

\footnotetext{
${ }^{31}$ Sobre as publicaçôes de Machado em O Cruzeiro, ver GLEDSON, John; GRANJA, Lúcia. Introdução. In: ASSIS, Machado de. Notas semanais. Campinas: Ed. da Unicamp, 2008.

32 O Cruzeiro, 21 maio 1878, p. 1.

${ }^{33}$ A imagem serviu de ilustração para um texto sobre um projeto para a implantação de uma linha férrea para o Vesúvio. Ilustraçâo Brasileira, n. 2, 15 de jul. 1876, imagem p. 15 e texto p. 31.
} 
Outro resultado alcançado com as referências ao passado era o de garantir aos leitores um indispensável conhecimento sobre o famoso vulcão, necessário a todo aquele que desejasse se aproximar dos círculos letrados na sociedade fluminense. Na formação escolar do Rio de Janeiro oitocentista os estudos relacionados com a antiguidade ocupavam um espaço importante e não é difícil imaginar que o Vesúvio fosse um desses itens intransponíveis no repertório da "tradição clássica". ${ }^{34}$ Os jornais, por sua vez, ajudavam a popularizar o tema.

Mas, se as referências estavam voltadas para o passado, elas também se apoiavam no grande interesse que o vulcão despertava no presente. A partir de meados do século XVIII, o Vesúvio tinha se tornado uma escolha preferencial para aqueles que desejavam ter uma experiência ao mesmo tempo perturbadora e fascinante. $\mathrm{O}$ contato com a montanha passou a se oferecer como uma das possibilidades de experimentar, e de representar, uma natureza grandiosa e ao mesmo tempo terrível, capaz de aguçar a sensação do sublime. ${ }^{35} \mathrm{E}$ os textos jornalísticos, ao longo do século XIX, também souberam fazer uso dessa ambivalência entre o horror e o fascínio que a erupção vulcânica era capaz de despertar. Na erupção de 1850, o Jornal do Comércio publicou um texto que dizia: "O Vesúvio acha-se em plena erupção, apresentando um espetáculo mais belo do que quantos há muitos anos se tem visto." ${ }^{36}$ Em março de 1868 foi possível ler no Diário do Rio de Janeiro: "A multidão de curiosos é imensa, e todos vão até a proximidade das pequenas correntes de lava para nela fincar algum objeto que é recolhido como memória, com o pedaço de lava apenas esfriada." ${ }^{37}$

O periódico fluminense Diário de Notícias, em sua edição de 23 de maio de 1872, dizia: "Uma nova erupção do Vesúvio lançou o pânico e a consternação em todas as povoaçóes vizinhas." E completava: "Muitos ingleses, apenas tiveram conhecimento do fenômeno, saíram da Inglaterra em direção a Nápoles." ${ }^{38}$ Dois anos mais tarde, a edição de 7 de fevereiro de 1874 do Jornal do Comércio trazia novidades vindas de Nápoles relatadas nos seguintes termos: os estrangeiros dirigem-se "em chusmas" ao vulcão depois que o diretor do Observatório, o professor Palmieri, anunciou que uma erupção estava próxima. "Os hotéis enchem-se de viajantes, e torna o júbilo a inundar a face dos honestos industriais que vivem às custas dos estrangeiros, embora a lava do vulcão possa sepultar vilas e aldeias da circunvizinhança do monte." ${ }^{39}$

\footnotetext{
${ }^{34}$ Sobre a importância da "tradição clássica" na formação escolar, ver TURIN, Rodrigo. A prudência dos antigos: figuraçôes e apropriações da tradição clássica no Brasil oitocentista. O caso do Colégio Imperial Pedro II. Anos 90, Porto Alegre, v. 22, p. 299-320, 2015.

${ }^{35}$ Ver DUFFY, Cian. "This astonishing convulsion of nature": Vesuvius and the spectacle of eruption. In: The Landscapes of the Sublime 1700-1830: Classic Ground. Londres: Macmillan, 2013 e ANDREWS, Noam. Volcanic rhythms: sir William Hamilton's love affair with Vesuvius. Architectural Association School of Architecture, n. 60, p. 9-15, 2010. A obra de Edmund Burke sobre o sublime e o belo, publicada em 1757, é uma referência fundamental para o tema. Ver BURKE, Edmund. Uma investigação filosófica sobre a origem de nossas ideias do sublime e do belo. Campinas, SP: Papirus; Ed. da Unicamp, 1993.

${ }^{36}$ Jornal do Comércio, 16 abr. 1850, p. 1.

${ }^{37}$ Diário do Rio de Janeiro, 6 mar. 1868, p. 2.

${ }^{38}$ Diário de Notícias, 23 maio 1872, p. 2.

${ }^{39}$ Jornal do Comércio, 7 fev. 1874, p. 2.
} 


\section{A erupção vulcânica como espetáculo}

Apresentações de diversos tipos de entretenimentos óticos anteriores ao cinema, comuns nas capitais europeias, eram exibidas no Rio de Janeiro - provavelmente em versôes portáteis - e anunciadas nos jornais. O Teatro de São Francisco de Paula (que mais tarde reabriria como Ginásio Dramático ${ }^{40}$ ) apresentou, no ano de 1835, o espetáculo "O mundo em miniatura”, em que o público era convidado a apreciar vistas animadas de uma aldeia na Suíça, de uma lagoa na Itália, de Marselha, o porto francês e, finalmente, de Nápoles, durante uma erupção do Vesúvio. ${ }^{41}$ No ano anterior, em 1834, o público tinha sido convidado a ver cenas como "o amanhecer nas cercanias do Cairo", "o meio-dia em Mont Blanc, na Suíça" ou "o Vulcão do Monte Vesúvio e Cidade de Nápoles, vistos de noite", todos no Cosmorama da rua do Ouvidor. ${ }^{42}$ Ediçóes do ano de 1835 do Jornal do Comércio anunciavam um diorama, também na rua do Ouvidor, em que era possível ver uma coleção de "vistas perfeitas, em ponto grande", que incluíam o "famoso monte Vesúvio" em erupção, visto de dia e "o mesmo visto de noite, todo abrasado, vomitando torrentes de fogo e cinza", ao lado de vistas de Constantinopla e da ilha de Santa Helena, com Napoleão e os ingleses. ${ }^{43}$

Em junho de 1837 foram anunciadas lindas vistas a serem expostas ao público, entre elas uma do vulcáo Vesúvio na erupção de 1832.44 Já o cosmorama exposto na rua do Lavradio, n. 35, em agosto de 1855, juntava vistas da quinta do duque de Palmela, do Vesúvio de Nápoles, do Colosso de Rodes e de fatos importantes da Rússia.

Muito comuns nas grandes cidades ao longo do século XIX, as apresentaçôes de entretenimentos óticos - cada vez mais estudados como uma linguagem própria e não uma proto-história do cinema ${ }^{45}$ - foram bastantes populares no Rio de Janeiro. ${ }^{46}$ As vistas do Vesúvio em erupção ou do golfo de Nápoles com o vulcão ao fundo faziam parte do repertório desses equipamentos desde os primeiros modelos franceses.

A representação do Vesúvio tinha uma longa e variada tradição na Europa, que passava por casos únicos, como o da réplica tridimensional construída nos jardins de Wörlitz, na cidade alemá de Dessau, entre 1788 e 1794, e equipada com um mecanismo para a encenação de erupçóes, ${ }^{47}$ até chegar aos panoramas, cosmoramas, dioramas e outros formatos, e

\footnotetext{
${ }^{40}$ Ver MAURÍCIO, Augusto. Algo do meu velho Rio. Rio de Janeiro: Brasiliana, 1966, p. 195-196.

${ }^{41}$ Jornal do Comércio, 28 jul. 1835, p. 3.

${ }^{42}$ Jornal do Comércio, 17 abr. 1834, p. 3.

${ }^{43}$ Jornal do Comércio, 4 jul. 1835, p. 4.

${ }^{44}$ Jornal do Comércio, 14 jun.1837, p. 4.

${ }^{45}$ Ver, principalmente sobre os panoramas móveis, HUHTAMO, Erkki. Illusions in motion: media archaeology of the moving panorama and related spectacles. Cambridge: MIT Press, 2013.

${ }^{46}$ Ver GONZAGA, Alice. Palácios e poeiras: 100 anos de cinema no Rio de Janeiro. Rio de Janeiro: Funarte, 1996 e ABREU, Martha. O Império do Divino: festas religiosas e cultura popular no Rio de Janeiro, 18301900. Rio de Janeiro: Nova Fronteira, 1999.

${ }^{47}$ Ver DARLEY, Gillian. Vesuvius: the most famous volcano in the world. Cambridge: Harvard University Press, 2012, p. 125-130.
} 
daí para as caixas portáteis, que se espalharam pelo mundo afora e que atraíam um público numeroso.

Algumas edições do Jornal do Comércio de junho de 1855 traziam anúncios da "Barraca da Crimeia", no Campo da Aclamação (Campo de Santana), um espaço tradicionalmente ocupado pelas festas populares, onde o respeitável público podia apreciar cenas da guerra da Crimeia, iniciada em 1853, mas também "vistas do Vesúvio em Nápoles e outras diversas", assim como uma exposição de "objetos de história natural". ${ }^{48}$

Além disso, os jornais deixam saber que o vulcão também estava presente em cenários para o teatro. ${ }^{49}$ E não era impossível adquirir na cidade gravuras, ou pinturas, do vulcáo. Em 23 de julho de 1871, segundo um anúncio publicado no Jornal do Comércio, quem comparecesse ao leilão no Salão da Confeitaria dos Srs. Schroeder \& C., na rua Primeiro de Março, antiga rua Direita, encontraria à venda um rol de mercadorias que incluía material táo variado como roupas, chapéus, tapetes, um barômetro e um "rico quadro, fina pintura a óleo" do Vesúvio. ${ }^{50}$ E mesmo brincos e outros adereços confeccionados com a lava do vulcáo - comuns na moda vitoriana - estavam disponíveis no comércio local e eram anunciados nos jornais. ${ }^{51}$

Essa rica presença visual (nos periódicos ilustrados, nas vistas animadas, nos quadros a óleo ou nos cenários para o teatro) sugere que o vulcáo pode ter tido um público mais abrangente do que exclusivamente o do leitor do texto impresso. E que, afinal, a cidade oferecia meios variadíssimos de pertencer à comunidade mundial daqueles que conheciam - $\mathrm{e}$ cultuavam - o vulcâo.

\section{A imperatriz napolitana e o líder republicano}

Os espetáculos de vistas animadas do Vesúvio ganharam um sentido particular na cidade - que os anúncios na imprensa local souberam explorar — com a chegada da imperatriz napolitana Teresa Cristina, em 1843, casada com d. Pedro II. Um "Comunicado" no Diário do Rio de Janeiro de 26 de outubro de 1843 dizia que apesar de não existir a intenção de pegar mais uma vez na pena para falar da Galeria Ótica, já tantas vezes mencionada, uma nova exposição itinerante na capital obrigava a que se escrevesse sobre o tema ainda uma vez. A exposição era um diorama, "obra em que fraternizam as belas artes com as mecânicas", e mostrava um "quadro perfeitamente executado do golfo e cidade de Nápoles".

${ }^{48}$ Ver, por exemplo, Jornal do Comércio, 6 jun. 1855, p. 4.

${ }^{49}$ Diário do Rio de Janeiro, 15 ago. 1862, p. 4. Sobre a presença do Vesúvio nas óperas, na Europa, ver DALY, Nicholas. The volcanic disaster narrative: from pleasure garden to canvas, page, and stage. Victorian Studies, v. 53, n. 2, p. 255-285, 2011.

${ }^{50}$ Jornal do Comércio, 23 jul. 1871, p. 4.

${ }^{51}$ Adereços confeccionados com lava do Vesúvio parecem ter tido uma vida longa, foram encontrados em anúncios dos anos de 1844 (Diário do Rio de Janeiro, 9 jul., p. 3), 1864 (3 out., p. 4) e 1874 (Jornal do Comércio, 6 jun., p. 6). 
O jornal perguntava: "Qual o Brasileiro que com avidez não contemple os lugares que viram nascer a nossa adorada Imperatriz, este anjo com que a providência brindou o Brasil?" Em seguida, descrevia as transformaçóes sofridas pela imagem durante a apresentação do diorama, cujo funcionamento era baseado nas mudanças de iluminaçáo:

No fundo eleva-se o Vesúvio (...). É dia; nuvens ligeiras cobrem parte do céu; densos vapores, e todavia transparentes, sobem da cratera do monte ignívomo, cujas chamas ainda são empalidecidas pelo clarão do dia. Pouco a pouco porém diminui o brilho do sol (...). Finalmente é noite completa; a cidade já não vê-se, só as chamas do Vesúvio lançam uma luz medonha sobre os objetos vizinhos e se miram nas ondas do golfo (...). Mas já aparece a lua, e em suave claro escuro emenda a paisagem, deixando-nos naquela doce melancolia, que quase sempre um belo luar em lugar solitário em nós desperta. ${ }^{52}$

E o jornal concluiu: "Quem não achar a mais perfeita imitação da natureza n'esta exposição, não sabemos onde poderá achar." ${ }^{3}$

A associação entre a esposa napolitana de d. Pedro II e o Vesúvio chegou à cidade antes da imperatriz. Teresa Cristina Maria de Bourbon, princesa do reino das Duas Sicílias, desembarcou no Rio de Janeiro, já casada, em setembro de 1843. Meses antes, durante as negociaçôes para o casamento, que se realizou por procuração, o secretário da legação brasileira teria trazido para d. Pedro o retrato da noiva. Atribuída ao pintor José Correia de Lima, a tela pertence atualmente ao acervo do Museu Imperial de Petrópolis. No retrato, Teresa Cristina usa um broche com a figura do imperador e o Vesúvio aparece ao fundo, exibindo a grossa coluna de fumaça táo frequente em suas representaçóes oitocentistas.

O vulcão também esteve presente em outra tela, esta exposta ao público, no Rio de Janeiro, em 1843. Retratando uma parada militar em Nápoles, a obra do pintor italiano Alessandro Ciccarelli fez parte da exposição da Academia de Belas Artes daquele ano. Segundo hipótese geralmente aceita, Ciccarelli integrava a comitiva da imperatriz Teresa Cristina, como seu professor de desenho, e assim veio para o Rio. ${ }^{54} \mathrm{O}$ crítico Araújo Porto-Alegre, em artigo que publicou sobre a exposição na Minerva Brasiliense (1843), descreveu os personagens centrais que compunham a cena da revista às tropas no "quadro do Sr. Cicarelli" e observou: "no fundo do quadro vê-se o Vesúvio", esse "monumento terrível" que indica Nápoles, "como o Pão d'Açúcar também é o monumento que indica o Rio de Janeiro, como as pirâmides, Memphis, ou São Pedro a cidade de Roma". ${ }^{55}$ Mais para o final do século, uma

\footnotetext{
${ }^{52}$ Diário do Rio de Janeiro, 26 out. 1843, p. 1.

${ }^{53}$ Idem.

${ }^{54}$ Ver LIMA, Valéria. Alessandro Ciccarelli e a tela "Casamento por procuração da imperatriz d. Teresa Cristina”: um ensaio interpretativo. In: VALLE, Arthur; DAZZI, Camila (Org.). Oitocentos - Arte brasileira do império à república. Seropédica: EDUR-UFRJ, 2010, v. 2, p. 657-669.

${ }_{55}^{5}$ PORTO-ALEGRE, Manuel de Araújo. Exposição pública. Minerva Brasiliense, Rio de Janeiro, v. 1, n. 4, 1843 , p. 120.
} 
matéria no periódico O Futuro: jornal artístico, cientifico, literário e recreativo comentou a exposição dos alunos da Academia de Belas Artes em 1872, informando que entre os trabalhos da aula de paisagem estavam as obras "O Aqueduto da Carioca, Gruta de Salteadores em Nápoles, Luar em Nápoles, Quinta da Boa Vista, e o Vesúvio", do aluno Antônio de Oliveira Fernandes Júnior. ${ }^{56}$

Ainda durante as cerimônias do casamento da imperatriz em Nápoles, uma visita do rei e da rainha das Duas Sicílias à fragata imperial Constituição, antes da partida de Teresa Cristina para o Brasil, em junho de 1843, foi tema de uma aquarela hoje pertencente ao acervo da Biblioteca Nacional, no Rio de Janeiro. Na imagem, os navios estão ancorados na baía de Nápoles e, ao fundo, lá está o Vesúvio, com o seu penacho de fumaça. ${ }^{57}$

Um integrante da comitiva enviada à Itália para os preparativos do casamento, o cônego Manoel Joaquim da Silveira, escreveu um relato da viagem que fez a Nápoles, publicado na Minerva Brasiliense no ano seguinte. ${ }^{58}$ Em sua narrativa, a que chamou "Itinerário", o cônego contou que participou das festividades do casamento, em seguida fez uma excursão a Roma e retornou a Nápoles, quando então visitou Pompeia e outras ruínas da região, e o Vesúvio, antes de embarcar de volta para o Rio. Partindo na companhia de um grupo, inclusive com outros brasileiros, sua visita ao vulcão foi feita a cavalo e já no final da tarde. No meio da subida, o seu cavalo deu para correr e ele acabou isolado do grupo, junto com o seu guia. Depois do que descreveu como uma muito penosa travessia pela lava íngreme, chegou finalmente ao cume da montanha, quando entáo teria ficado exposto a terrível perigo: "Momento fatal! Uma coluna de negro espesso fumo, através da qual fulguravam línguas de vermelho lume, se elevava aos ares do fundo da cratera com horrível estampido, que ecoou nos vales (...)". Conferindo um pouco mais de dramaticidade a seu relato, e seguindo na tópica dos contrastes, escreveu:

Meia hora contemplei a forja em que não cessava o trabalho. Do fundo da cratera se arremessavam pedras, que nela outra vez caíam com fracasso. A abóbada celeste diáfana e marchetada de estrelas que cintilavam com viveza contrastava com o objeto medonho que tinha a meus pés. ${ }^{59}$

\footnotetext{
${ }^{56}$ O Futuro: jornal artístico, cientifico, literário e recreativo, 17 dez. 1872, p. 1.

${ }^{57}$ M. d'Anna. Aquarela, 1844. Iconografia, ARC.30-E:b:III. Fundação Biblioteca Nacional.

${ }^{58}$ Ver GUIMARÁES, Lucia Maria Paschoal. Um brasileiro na península itálica: impressóes de viagem do cônego Manoel Joaquim da Silveira (1843). In: CARVALHO, José Murilo de; NEVES, Lucia Maria Bastos Pereira (Org.). Dimensóes e fronteiras do Estado brasileiro no oitocentos. Rio de Janeiro: Eduerj, 2014. O médico e botânico Francisco Freire Alemão, outro membro da comitiva que foi buscar a imperatriz, também visitou o Vesúvio. Ver Annaes Brasilienses de Medicina. Tomo XXVII, n. 8, jan. 1876, p. 479.

${ }^{59}$ SILVEIRA, M. J. da. Itinerário da viagem que fez a Nápoles (...). Minerva Brasiliense, Rio de Janeiro, n. 8 , p. 236,15 fev. 1844 .
} 
Ao longo da segunda metade do século XIX, as narrativas de subidas ao Vesúvio como a do cônego se popularizaram e de tempos em tempos os leitores tinham acesso a matérias como a que foi publicada na seção de Variedades do Jornal do Comércio, em 23 de julho de 1878, intitulada "Uma ascensão ao Vesúvio"60; e assim o público fluminense também passava a integrar a legiâo de consumidores das narrativas de viagem à Itália, e ao Vesúvio, no oitocentos.

A imperatriz Teresa Cristina era filha de Francisco I, rei das Duas Sicílias, e irmá de Ferdinando II, que herdou o trono do pai. Indo viver no Brasil, correspondeu-se com o irmão e recebeu numerosas peças escavadas nas cidades romanas provenientes do Real Museu de Nápoles, e que foram incorporadas ao Museu Nacional, no Rio de Janeiro. ${ }^{61}$

Algumas dessas peças foram mencionadas por Thomas Ewbank. Nascido na Inglaterra, mas vivendo nos Estados Unidos, Ewbank esteve no Brasil em 1846, por seis meses, e em seu livro A vida no Brasil; ou diário de uma visita à terra do cacaueiro e das palmeiras (1856), descreveu uma ida ao Paço Imperial de São Cristóvão:

No peitoril de uma janela havia antiguidades de Herculano e Pompeia (...). Todas eram cobertas com uma dura crosta verde, que em um dos vasos estava um pouco raspada, deixando ver por baixo o metal, tão liso e polido quanto um moderno aparelho de chá saído da fábrica. ${ }^{62}$

Em janeiro de 1857, o Jornal do Comércio noticiou uma doação para o Museu do Rio de Janeiro de "um magnífico presente de antiguidades pompeianas" do Museu Bourbônico de Nápoles: "O Museu Nacional acaba de receber 260 objetos, tais como vasos ítalo-gregos, pintados e de terra cozida, vidros, bronzes e pinturas a fresco." ${ }^{\text {"3 }}$ Com a doação, o Rio ingressava no rol das cidades que tinham o privilégio de possuir um acervo arqueológico da região do Vesúvio, com todo o prestígio que essas coleçóes conferiam.

Durante o reinado do pai e do irmão da imperatriz, Pompeia tinha se transformado num lugar de visitação para príncipes e outros hóspedes ilustres e costumava recebê-los com as chamadas "descobertas", encenaçóes preparadas pela direção das escavaçóes, em honra dos vi-

\footnotetext{
${ }^{60}$ Jornal do Comércio, 23 jun. 1878, p. 2. A escritora brasileira Nísia Floresta viajou pela Itália, entre 1858 e 1861, e publicou em Paris uma narrativa de viagem com dois capítulos dedicados ao Vesúvio: "Uma subida ao Vesúvio" e "Uma erupção do Vesúvio". FLORESTA, Nísia. Três anos na Itália seguidos de uma viagem à Grécia. Natal: EDUFRN, 1998. v. 1.

${ }^{61}$ Ver CORDISCHI, Lanfranco. A coleção de antiguidades no Rio e os interesses arqueológicos da Imperatriz Teresa Cristina Maria. In: JACOBELLI, Luciana (Ed.). Além de Pompeia: redescobrindo os encantos de Stabiae. Rio de Janeiro: Eduerj, 2012. Sobre a coleção do Museu Nacional, ver também Afrescos de Pompeia: a beleza revelada. Catálogo da mostra realizada no Rio de Janeiro entre 12 de abril e 29 de maio de 2005. Sobre a imperatriz, foi publicada recentemente uma biografia, AVELLA, Anielo A. Teresa Cristina de Bourbon: uma imperatriz napolitana nos trópicos, 1843-1889. Rio de Janeiro: Eduerj, 2014.

${ }^{62}$ EWBANK, Thomas. A vida no Brasil; ou, diário de uma visita à terra do cacaueiro e das palmeiras. Belo Horizonte: Itatiaia; São Paulo: Edusp, 1976, p. 116.

${ }^{63}$ Jornal do Comércio, 23 jan. 1857, p. 2.
} 
sitantes, em que se "achavam" peças que na verdade já tinham sido encontradas anteriormente, e reenterradas. ${ }^{64} \mathrm{~A}$ cidade destruída passava a ser um destino ao alcance de alguns poucos, mas presente no horizonte de muitos, como um sonho longínquo a ser alcançado; ou pelo menos a ser desfrutado através, por exemplo, da leitura das populares narrativas de viagem.

O casal imperial, Teresa Cristina e Pedro II, nos itinerários que percorreu em suas viagens pela Europa, como não poderia deixar de ser, foi a Nápoles (a cidade natal da imperatriz) e visitou as ruínas das cidades soterradas. Em 1888, o casal se fez fotografar, com sua comitiva, em Pompeia. O trabalho foi realizado pelo concorrido estúdio fotográfico de Giorgio Sommer. Alemão, radicado em Nápoles, Sommer tinha fotografado Pompeia e Herculano ao longo de duas décadas, produzindo álbuns que alcançaram grande prestígio e ajudaram a tornar as ruínas conhecidas do público.

Capturada na fotografia de Giorgio Sommer (Figura 2), a visita do casal a Pompeia (divulgada através de relatos na imprensa fluminense) ajudava a aproximar os súditos brasileiros deste cobiçado destino. E de alguma forma os tornava herdeiros, por extensão, de um passado grandioso (dos impérios da antiguidade) que a erupção vulcânica tinha congelado no tempo. No imaginário em torno da monarquia, ${ }^{65}$ a ideia de pertencimento à tradição europeia através da figura da imperatriz ganhava força.

Figura 2: Pedro II, Teresa Cristina Maria e comitiva em visita às ruínas de Pompeia. Giorgio Sommer. Fotografia, [1888]. Coleçáo Thereza Christina Maria. Fundaçáo Biblioteca Nacional.

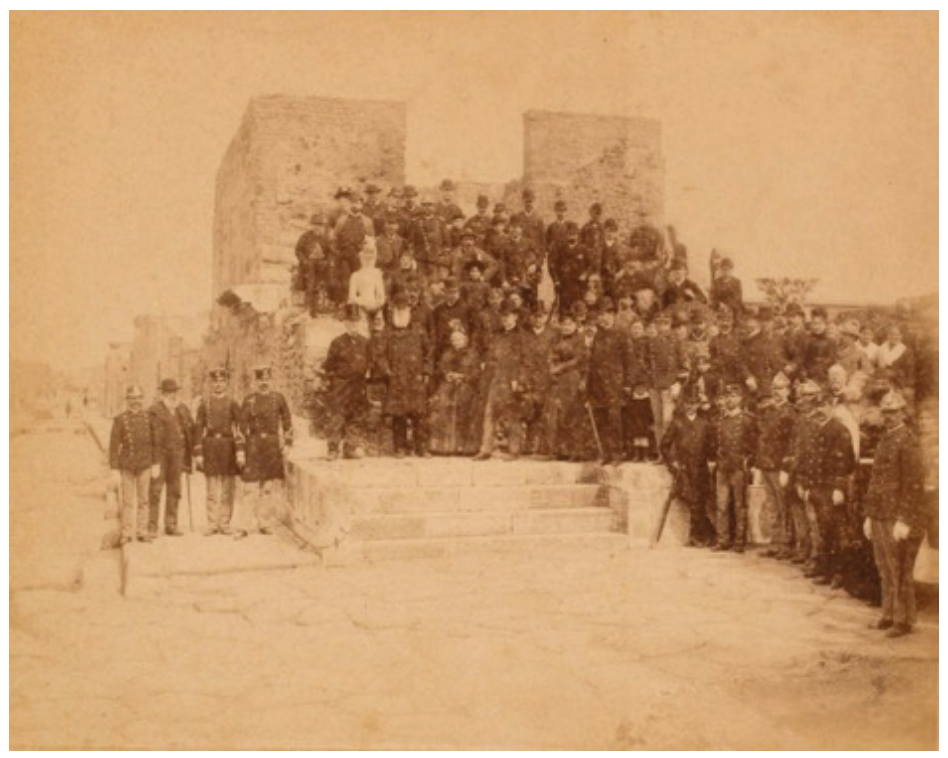

${ }^{64}$ CORTI, Egon C. C. Vida, morte e ressurreição de Herculano e Pompéia. Belo Horizonte: Itatiaia, 1958, p. 236.

${ }^{65}$ Sobre imaginário, ver BACZKO, Bronislaw. Los imaginários sociales: memorias y esperanzas colectivas. Buenos Aires: Ediciones Nueva Visión, 1991. 
Mas não foram apenas as cidades desenterradas das cinzas que interessaram ao casal imperial. Como faziam tantos visitantes, eles também demonstraram interesse especial pelo Vesúvio, o que não escapou ao olhar ávido da imprensa fluminense. O Diário do Rio de Janeiro noticiou a viagem de 1871, quando, segundo o jornal, o casal fez o circuito "Museu Bourbônico, Vesúvio, Pompeia, Herculano" 66 e outras atraçôes próximas. A Chronica Nacional, ou Novo e completo indice chronologico da Historia do Brasil, publicada pela Tipografia Laemmert, incluiu entre os fatos notáveis do ano de 1877 a viagem do imperador à Europa. A Chronica narrou a chegada do casal a Nápoles no dia 31 de janeiro daquele ano, escrevendo: apesar da penosa viagem de mais de 24 horas, no dia seguinte, às sete horas da manhã o imperador já se achava na estrada "em carruagem aberta, contemplando o panorama e o Vesúvio cintilante de neve". ${ }^{67}$ Ao meio-dia, estava no Museu de Nápoles. No dia 6, a imperatriz quis visitar o túmulo de seus parentes e à tarde "o célebre professor Palmieri, conhecido pelas observaçóes do Vesúvio", foi apresentado ao imperador. No dia 9 foram ao Observatório vesuviano e três dias mais tarde partiram para Roma.

A viagem do casal em 1888 foi narrada pelo próprio imperador em seu diário. No dia 16 de abril daquele ano, d. Pedro anotou a visita que fez a Capri, e ainda à ilha de Ischia, para ver "as ruínas de Casamicciola", na baía de Nápoles. ${ }^{68}$ Em 28 de julho de 1883, a cidade de Casamicciola, muito frequentada por seus banhos termais, tinha sido sacudida por um terremoto que deixou um número elevado de vítimas. Em 1881 tinha havido outro tremor. E tanto o abalo de 1883 como o anterior tinham sido acompanhados pela imprensa, inclusive no Rio. O Jornal do Comércio publicou extensos relatos sobre os tremores, principalmente sobre o segundo, o de 1883, quando a notícia do desastre tinha chegado quase imediatamente, por telegrama. ${ }^{6}$

D. Pedro visitou a casa arruinada dos banhos e o teatro de Casamicciola, anotando no diário: "Acompanhou-me o síndico Menella que muito sofreu com o terremoto, ficando-lhe a filha paralítica". E como última anotaçáo do dia recorreu ao vulcão: "Como está belo o Vesúvio todo cor de rosa desmaiada!"

No dia seguinte, ida ao vulcáo. Depois de almoçar no hotel perto do plano inclinado, o imperador subiu a pé até a borda da cratera e as senhoras subiram em cadeiras carregadas por quatro homens. No diário, narrou assim o que viu: "Fumegava bastante e atirava às vezes pedras a grande altura. Era um belo espetáculo. Depois visitei o observatório onde se estudam os fenômenos e fazem-se coleçôes relativas ao Vesúvio. Palmieri aí estava; tudo me mostrou

\footnotetext{
${ }^{66}$ Diário do Rio de Janeiro, 31 dez. 1871, p. 1.

${ }^{67}$ Chronica Nacional, ou Novo e completo indice chronologico da Historia do Brasil (1842 a 1889). Rio de Janeiro: Typ. Universal de Laemmert, s.d., p. 225-226.

${ }^{68}$ Diários do imperador d. Pedro II. Volume 27. 3a viagem ao exterior. Primeira parte 30/06/1887 a 26/04/1888. Arquivo Histórico. Museu Imperial.

${ }^{69}$ Jornal do Comércio, 31 jul. 1883, Telegramas, p. 1.
} 
e prometeu-me suas últimas publicaçôes." ${ }^{70}$ A narrativa do imperador não se afastou, assim, da tópica sempre presente na descrição do vulcão, terrível e belo.

\section{Figura 3. Família imperial brasileira no vulcáo Vesúvio (Itália). Giorgio Sommer. Fotografia [1888]. Museu Mariano Procópio.}

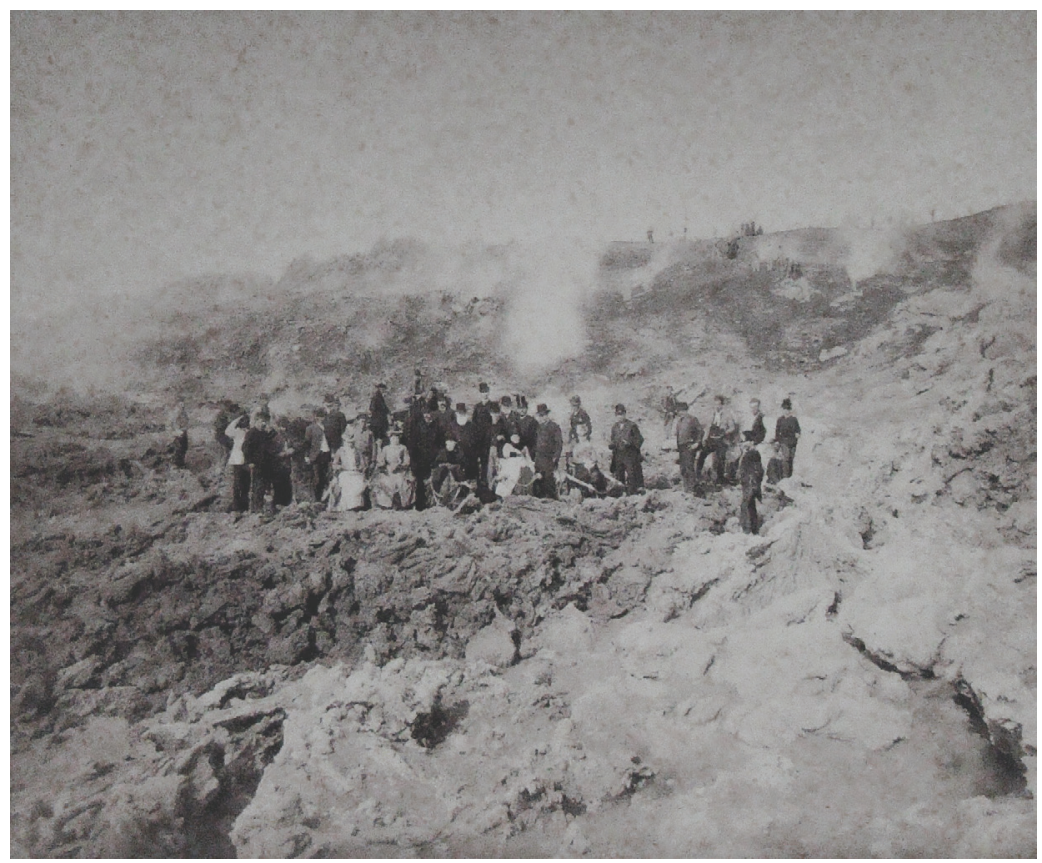

$\mathrm{Na}$ visita, o casal imperial também se fez fotografar, com sua comitiva (Figura 3). O terreno retorcido, de lava solidificada, visível desde o primeiro plano, e os vapores, as chamadas fumarolas, no fundo da imagem, inserem o grupo na paisagem vulcânica. À primeira vista, o grupo segue, pelo menos em parte, uma arrumação tradicional na fotografia oitocentista, com os homens atrás e as mulheres sentadas comodamente na primeira fila. Um olhar mais próximo revela, no entanto, que as mulheres estão sentadas em estranhas cadeiras, provavelmente as que eram usadas pelos carregadores mencionados no diário do imperador.

A fotografia também é de Giorgio Sommer, como as que foram feitas em Pompeia. Um dos primeiros fotógrafos a escolher o monte Vesúvio como tema, Sommer tinha ajudado a inserir o vulcão na geografia do sublime. ${ }^{71} \mathrm{Na}$ grande erupção de 26 de abril de 1872, capturou a atividade vulcânica em diferentes horários e produziu uma série fotográfica que se tornou muito conhecida. Acompanhou diversos grupos em visita ao Vesúvio. Na fotografia de 1888, o imperador brasileiro e sua comitiva formavam mais um grupo de visitantes destemidos, quase engolidos pela paisagem grandiosa e terrificante do solo vulcânico.

\footnotetext{
${ }^{70}$ Diários do imperador d. Pedro II. Volume 27. 3a viagem ao exterior. Primeira parte 30/06/1887 a 26/04/1888. Arquivo Histórico. Museu Imperial.

${ }^{71}$ Ver HANNAVY, John (Ed.). Encyclopedia of Nineteenth-Century Photography. Nova York: Routledge, 2008.
} 
Finalmente, a última grande aparição do vulcão nos jornais oitocentistas do Rio de Janeiro ocorreria em 1891. Em seu exílio na Europa, o maior propagandista da república recém-inaugurada encontrava a morte na cratera do Vesúvio. Nas proposiçôes de Francisco Foot Hardman, Silva Jardim pode ser filiado — até na morte — às concepçóes românticas do sublime, em que estaria inserido o desejo irrefreável de desafiar uma natureza infinita e terrível. ${ }^{72}$ Silva Jardim partiu para um passeio sabidamente arriscado nas bordas do Vesúvio.

As percepçôes da imprensa sobre a morte do republicano parecem ter seguido as convençôes do século sobre o vulcão. A Revista Ilustrada escreveu: "O Vesúvio - o engole cidades, tomou a si o triste encargo de furtar ao Brasil um de seus filhos que mais o estimaram e que mais lutaram por ele." O texto dizia: "Depois de uma vida atribulada, exclusivamente dedicada ao país em que viveu e nasceu, Silva Jardim teve a mais feliz, a mais rápida de todas as mortes." ${ }^{73} \mathrm{E}$ em meio às diversas notícias sobre a tragédia publicadas na imprensa fluminense, o leitor de $O$ Século pôde finalmente concluir, ajudado pelo texto de José do Patrocínio: "Bela sepultura o vulcão, extraordinário destino o do grande brasileiro; até para morrer converteu-se em lava." 74

Assim o vulcão, que tinha participado do imaginário político do segundo reinado com a imperatriz Teresa Cristina, entrava no campo republicano com a morte de Silva Jardim, um dos maiores críticos do regime monárquico. Usado largamente pela monarquia, agora atendia a um novo ideário e servia de sepultura digna para o jovem líder republicano que tinha morrido no exílio.

\section{Conclusão}

De acordo com o que se pretendeu mostrar, esse uso político de longo prazo e até em direçóes opostas foi possível, ou ao menos facilitado, justamente porque o vulcão já era um velho conhecido quando a imperatriz chegou à cidade na década de 1840 . A sua poderosa imagem de uma natureza aterradora e fascinante já circulava, entre o erudito e o popular, no Rio de Janeiro das primeiras décadas do século XIX. Como acontece com frequência na construção de mitologias políticas, elas precisam assentar em um terreno prévio e esse terreno estava pronto, pelo menos na capital. E provavelmente também em outras áreas do país.

\footnotetext{
${ }^{72}$ HARDMAN, Francisco Foot. Silva Jardim: a República e o vulcão. Estudos Avançados, São Paulo, v. 12, n. 34, set./dez. 1998.

${ }^{73}$ Revista Ilustrada, n. 625, p. 2, 1891.

${ }^{74}$ José do Patrocínio. O Século, 12 jul. 1891. Citado em JARDIM, Silva. Memórias e viagens: campanha de um propagandista. Lisboa: Typ. da Companhia Nacional Editora, 1891.
} 
Na construção de imaginários políticos, importar modelos não é um problema, o importante é como eles são adaptados na sociedade local. ${ }^{75} \mathrm{E}$ na sociedade local é que se operou essa junção entre o vulcão, a imperatriz e o líder republicano.

Também sobre o Vesúvio, Foot Hardman localizou uma crônica inédita do escritor recifense Alberto Rangel (1871-1945) intitulada "Pitoresco e estafa" e datada de junho de 1908, quando o escritor passou sua primeira temporada na Europa. A crônica, já moderna, narra uma excursão a Pompeia e ao Vesúvio, organizada nos moldes do turismo de massa, pela agência de viagens Cook: "uma profanação essa visita às pressas". E como se não bastasse a estafa de subir ao topo do vulcáo ao lado de turistas apressados, ainda há a humilhação das liçôes. "E, como eu contemplasse esse feio lençol terroso, na assolação de suas dobras imensas, um turista, à minha esquerda (...) dardejou-me os seus óculos esclarecedores.” Talvez um professor de geologia, num instituto imperial.

Arguto e benevolente, o doutor teve pena da minha ignorância crassa de latino, e explicou, com piedosa solicitude, o que meu cérebro de troglodita americano, diante o garabulho da lava nâo compreendera. E o ruivo professor anafado e oculoso, explicou-me sobriamente, apontando para o vômito resfriado do vulcáo:

— Lava!

Disse só isto, com medo de que a palavra preciosa se constituísse uma racha, por onde se escoasse e se perdesse o seu saber profundo dos fenômenos, que Plutão comanda. ${ }^{76}$

Mas quem precisava dessas liçóes? Mesmo para o mais modesto leitor de jornal nesta virada de século, o Vesúvio era tudo, menos um desconhecido. O comentário do turista apressado, e presunçoso, dirigido àqueles que conheciam o vulcão táo intimamente, era um verdadeiro insulto.

No século XX, com o fim da moda das visitas animadas, o Vesúvio não perderia sua fama mundial nem seu poder de entreter e divertir, ele faria sua apariçáo nas telas de cinema. ${ }^{77} \mathrm{Na}$ imprensa, no entanto, seria relegado, quase exclusivamente, sem abandonar seu posto de destino turístico, às matérias de divulgaçáo científica. Mas, mesmo nesse momento, a ambiguidade continuaria a marcar as representaçóes do vulcão; e afinal de todos os

\footnotetext{
75 Ver CARVALHO, José Murilo de. A formação das almas: o imaginário da República no Brasil. São Paulo: Companhia das Letras, 1990, p. 22.

${ }^{76}$ RANGEL, Alberto. Pitoresco e estafa. In: HARDMAN, Francisco Foot. Duas viagens a Nápoles. Papéis Avulsos, Rio de Janeiro, n. 32, p. 34-35, 1998.

77 Publicado em 1834, o livro de Edward Bulwer-Lytton, Os últimos dias de Pompeia, uma das obras mais populares do século XIX, recebeu nove adaptaçôes para o cinema entre 1900 e 1950. Ver DALY, N. The volcanic disaster narrative: from pleasure garden to canvas, page, and stage. Victorian Studies, v. 53, n. 2, p. 276, 2011. A obra foi traduzida em Portugal ainda no século XIX. No Brasil, segundo o Dicionário histórico-biográfico da Primeira República, da Fundaçáo Getulio Vargas, o jornalista e político piauiense Clodoaldo Freitas traduziu o livro em 1913.
} 
vulcôes, que passariam a ser entendidos como uma potência destruidora e, ao mesmo tempo, uma das forças criadoras da geografia do planeta.

\section{Referências bibliográficas}

ABREU, Alzira (Coord.). Dicionário histórico-biográfico da Primeira República (1889-1930). Rio de Janeiro: FGV, 2013.

ABREU, Martha. O Império do Divino: festas religiosas e cultura popular no Rio de Janeiro, 1830-1900. Rio de Janeiro: Nova Fronteira, 1999.

ANDREWS, Noam. Volcanic Rhythms: sir William Hamilton's love affair with Vesuvius. Architectural Association School of Architecture, n. 60, p. 9-15, 2010.

ARQUEMBOURG, Jocelyne. L'événement et les médias: les récits médiatiques des tsunamis et les débats publics (1755-2004). Paris: Éditions des Archives Contemporaines, 2011.

AVELLA, Anielo A. Teresa Cristina de Bourbon: uma imperatriz napolitana nos trópicos, 1843-1889. Rio de Janeiro: Eduerj, 2014.

BACZKO, Bronislaw. Los imaginários sociales: memorias y esperanzas colectivas. Buenos Aires: Ediciones Nueva Visión, 1991.

BELO, André. A gazeta de Lisboa e o terramoto de 1755; a margem do não escrito. Análise Social, Lisboa, v. 34, n. 151-152, p. 619-636, 2000.

BENOIT, Raffaella et al. Turismo e archeologia nel XIX secolo: il ruolo dell'anticonella promozione delle città campane. In: VI CONVEGNO INTERNAZIONALE DI STUDI CITTÀ MEDITERRANEE IN TRASFORMAZIONE. IDENTITÀ E IMMAGINE DEL PAESAGGIO URBANO TRA SETTE E NOVECENTO. Università degli Studi di Napoli Federico II. Nápoles: Edizioni Scientifiche, 2014.

BORGSTROM, Sven; DE LUCIA, Maddalena; NAVE, Rosa. Luigi Palmieri: first scientific bases for geophysical surveillance in Mt. Vesuvius area. Annali di Geofisica, Roma, v. 42, n. 3, jun. 1999.

BURKE, Edmund. Uma investigação filosófica sobre a origem de nossas ideias do sublime e do belo. Campinas, SP: Papirus; Ed. da Unicamp, 1993.

CARVALHO, José Murilo de. A formação das almas: o imaginário da República no Brasil. São Paulo: Companhia das Letras, 1990.

CIVETTA, Lucia et al. (Org.). Il Vesuvio negli occhi: storie di osservatori. Nápoles: Osservatorio Vesuviano/Istituto Nazionale di Geofisica e Vulcanologia, 2004.

COCCO, Sean. Watching Vesuvius: a History of Science and Culture in Early Modern Italy. Chicago: The University of Chicago Press, 2013. 
CORDISCHI, Lanfranco. A coleção de antiguidades no Rio e os interesses arqueológicos da Imperatriz Teresa Cristina Maria. In: JACOBELLI, Luciana (Ed.). Além de Pompeia: redescobrindo os encantos de Stabiae. Rio de Janeiro: Eduerj, 2012.

CORTI, Egon C. C. Vida, morte e ressurreição de Herculano e Pompéia. Belo Horizonte: Itatiaia, 1958.

CRESTANI, Jaison Luís. Sob o signo da rivalidade: o perfil editorial do jornal O Cruzeiro. Miscelânea, Assis, v. 14, p. 141-162, jul./dez. 2013.

DALY, Nicholas. The volcanic disaster narrative: from pleasure garden to canvas, page, and stage. Victorian Studies, v. 53, n. 2, p. 255-285, 2011.

DARLEY, Gillian. Vesuvius: the most famous volcano in the world. Cambridge: Harvard University Press, 2012.

DUARTE, Regina Horta. Natureza e sociedade, evolução e revolução: a geografia libertária de Elisée Reclus. Rev. Bras. Hist., São Paulo, v. 26, n. 51, p. 11-24, jun. 2006.

DUFFY, Cian. "This astonishing convulsion of nature": Vesuvius and the spectacle of eruption. In: The Landscapes of the Sublime 1700-1830: Classic Ground. Londres: Macmillan, 2013.

EWBANK, Thomas. A vida no Brasil; ou, diário de uma visita à terra do cacaueiro e das palmeiras. Belo Horizonte: Itatiaia; São Paulo: Edusp, 1976.

FLORESTA, Nísia. Três anos na Itália seguidos de uma viagem à Grécia. Natal: EDUFRN, 1998. v. 1.

GLEDSON, John; GRANJA, Lúcia. Introdução. In: ASSIS, Machado de. Notas semanais. Campinas: Ed. da Unicamp, 2008.

GOETHE, Johan Wolfgang. Viagem à Itália, 1786-1788. São Paulo: Companhia das Letras, 1999.

GONZAGA, Alice. Palácios e poeiras: 100 anos de cinema no Rio de Janeiro. Rio de Janeiro: Funarte, 1996.

GUIMARÁES, António J. Memoria sobre as ruínas e as antiguidades de Pompeia. Annaes da Sociedade Literaria Portuense. Porto: Imprensa de Alvares Ribeiro, 1837, p. 31-6.

GUIMARÁES, Lucia Maria Paschoal. Um brasileiro na península itálica: impressões de viagem do cônego Manoel Joaquim da Silveira (1843). In: CARVALHO, José Murilo de; NEVES, Lucia Maria Bastos Pereira das (Org.). Dimensóes e fronteiras do Estado brasileiro no oitocentos. Rio de Janeiro: Eduerj, 2014.

HANNAVY, John (Ed.). Encyclopedia of Nineteenth-Century Photography. Nova York: Routledge, 2008.

HARDMAN, Francisco Foot. Silva Jardim: a República e o vulcão. Estudos Avançados, São Paulo, v. 12, n. 34, set./dez. 1998.

HUHTAMO, Erkki. Illusions in motion: media archaeology of the moving panorama and related spectacles. Cambridge: MIT Press, 2013. 
JARDIM, Silva. Memórias e viagens: campanha de um propagandista. Lisboa: Typ. da Companhia Nacional Editora, 1891.

LIMA, Valéria. Alessandro Ciccarelli e a tela "Casamento por procuração da imperatriz d. Teresa Cristina”: um ensaio interpretativo. In: VALLE, Arthur; DAZZI, Camila (Org.). Oitocentos — arte brasileira do império à república. Seropédica: EDUR-UFRJ, 2010, v. 2, p. 657-669.

MADERUELO, Javier. La mirada pintoresca. Quintana, Santiago de Compostela, n. 11, p. 79-90, 2012.

MAURÍCIO, Augusto. Algo do meu velho Rio. Rio de Janeiro: Brasiliana, 1966, p. 195-196. MERCIER-FAIVRE, Anne-Marie; THOMAS, Chantal (Org.). L'invention de la catastrophe au XVIIIe siècle: du châtiment divin au désastre naturel. Genebra: Droz, 2008.

PATIERNO, Alvio. Vesuvius for Everyone in 19th Century France. In: ASCARI, Maurizio; CORRADO, Adriana (Org.). Sites of Exchange: European Crossroads and Faultlines. Amsterdá: Rodopi, 2006, p. 87-95.

PORTO-AlEGRE, Manuel de Araújo. Exposição pública. Minerva Brasiliense, Rio de Janeiro, v. 1, n. 4, 1843.

RANGEL, Alberto. Pitoresco e estafa. In: HARDMAN, Francisco Foot. Duas viagens a Nápoles. Papéis Avulsos, Rio de Janeiro, n. 32, p. 34-35, 1998.

SALGUEIRO, Valéria. Grand Tour: uma contribuição à história do viajar por prazer e por amor à cultura. Rev. Bras. Hist., v. 22, n. 44, p. 289-310, 2002.

SILVEIRA, Manoel Joaquim da. Itinerário da viagem que fez a Nápoles o cônego Manoel Joaquim da Silveira, na qualidade de capeláo da câmara de Sua Majestade a Imperatriz do Brasil - a Sra. D. Teresa Cristina Maria, a bordo da fragata Constituição. Minerva Brasiliense, Rio de Janeiro, v. 1, n. 4, 15 dez. 1843.

TURIN, Rodrigo. A prudência dos antigos: figurações e apropriações da tradição clássica no Brasil oitocentista. O caso do Colégio Imperial Pedro II. Anos 90, Porto Alegre, v. 22, p. 299-320, 2015.

WINCHESTER, Simon. Krakatoa: o dia em que o mundo explodiu. Rio de Janeiro: Objetiva, 2004.

WOOD, Gillen D'Arcy. Tambora: the eruption that changed the World. Princeton, NJ: Princeton University Press, 2014.

\section{Como citar}

ALMEIDA, Anita Correia Lima de. Pavoroso espetáculo: o culto ao Vesúvio no Rio de Janeiro oitocentista. Topoi. Revista de História, Rio de Janeiro, v. 18, n. 36, p. 490-513, set./dez. 2017. Disponível em: <www.revistatopoi.org>. 